\title{
Lactose malabsorption during gastroenteritis, assessed by the hydrogen breath test
}

\author{
ANDREW J GARDINER, MICHAEL J TARLOW, IAN T SUTHERLAND, AND \\ HERBERT G SAMMONS
}

Institute of Child Heath, University of Birmingham, and Department of Paediatrics and Department of Clinical Chemistry, East Birmingham Hospital

SUMMARY Thirty-eight infants and young children with gastroenteritis were investigated for lactose malabsorption. Each of them was given an oral lactose load of either $0.5 \mathrm{~g} / \mathrm{kg}$ or $2 \mathrm{~g} / \mathrm{kg}$ after which breath hydrogen excretion was measured, and each was observed to see if he had clinical symptoms of lactose intolerance. Only one patient, given $2 \mathrm{~g} / \mathrm{kg}$ lactose, had clinical intolerance. His breath hydrogen excretion however was negative. Three of 18 patients given $0.5 \mathrm{~g} / \mathrm{kg}$ lactose had positive breath hydrogen tests. None of these was symptomatic. Lactose intolerance in gastroenteritis was rare in our study, and the hydrogen breath test was not an appropriate technique for detecting it.

Gastroenteritis is an important cause of infant mortality and morbidity throughout the world, yet important differences in its manifestations have been noted in different populations. ${ }^{1-4}$

One of the principal clinical features of gastroenteritis, with implications for treatment, is the associated lactose intolerance which occurs. Its incidence seems to vary in different geographical areas and racial groups, perhaps in association with malnutrition and racial lactase deficiency. Lifshitz et al. ${ }^{5}$ studied 332 Mexican infants, $90 \%$ of whom were malnourished by their criteria, and found clinical evidence of lactose intolerance in $77 \%$.

A study of 31 Australian infants who were biopsied early in the course of gastroenteritis ${ }^{6}$ showed reduction of small-intestinal lactase activity in 16 of them. A similar study by Davidson and Barnes $^{7}$ in which rotavirus was isolated from all patients showed low lactase activity in 11 of 16 . However, clinical evidence of lactose intolerance in this latter group was said to be rare.

Clinical assessment of lactose intolerance during gastroenteritis may be inaccurate because of the possible confusion with the similar clinical features of the underlying disease. Laboratory tests are also often inconclusive. Stool testing by the Clinitest (Ames) method of Kerry and Anderson ${ }^{8}$ may fail to detect lactose malabsorption in some patients, ${ }^{9}$ perhaps because of catabolism of lactose by the colonic flora before excretion in faeces. Even direct estimation of small intestinal disaccharidase activity on biopsied samples does not assess overall sugar absorptive ability but just measures enzyme activity at a single point in the gut.

The hydrogen breath test has been claimed to be a reliable means of detecting lactose malabsorption in adults in a prospective study by Newcomer et al., ${ }^{10}$ and the test has been used to detect lactose intolerance in children. ${ }^{11}$ This suggested to us that it may be of use to explore the pathophysiology of lactose malabsorption in gastroenteritis.

\section{Patients and methods}

Patients. The study comprised 38 infants and young children presenting to a regional infectious disease referral centre with acute-onset diarrhoea, with or without vomiting. Those whose symptoms failed to persist after admission, those who had received antibiotics during the 7 days before admission, and those in whom there was evidence of extraintestinal infection as a possible cause for symptoms were excluded. All patients were considered sufficiently ill to justify inpatient care, and each was tested between the day of onset of symptoms and 32 days afterwards. All patients had stools cultured for bacterial and viral pathogens, and electron microscopical examination to detect rotavirus was routinely performed. Stool pathogens were Salmonella sp. (3), rotavirus (2), adenovirus (1), enteropathogenic Escherichia coli and Shigella sp. together (1), and coxsackievirus (1).

Of the 38, 27 were boys. The mean age of the group was 0.68 (range 0.07-3.80) years; 19 were white, 17 Indian or Pakistani, 1 Afro-Caribbean, and 1 of mixed race. 
Nutritional state was expressed in terms of standard weight for age based on the growth standards of Tanner. ${ }^{12}$ The weights of 25 patients exceeded $80 \%$ of the standard weight for age, 12 were between 60 and $80 \%$, and one was less than $60 \%$. Informed parental consent was obtained in each case.

Procedure. Patients were fasted for 6 hours, during the first 3 of which they were allowed oral $4 \%$ dextrose/saline by mouth. Lactose was administered in $10 \%$ by vol aqueous solution, at a dose of 0.5 or $2.0 \mathrm{~g} / \mathrm{kg}$ body weight. The smaller dose was initially chosen to avoid the risk of inducing a large osmotic fluid loss. Twenty patients were studied using this dose without the appearance of symptoms. In a further 18 patients the dose of lactose was increased to $2.0 \mathrm{~g} / \mathrm{kg}$, approximating the amount in a single milk feed appropriate for the infant's size. Patients were observed for clinical evidence of intolerance, and the first stool after ingestion was tested for reducing substances by the Clinitest method of Kerry and Anderson. ${ }^{8}$

Breath collection. Samples were obtained using the small size Rahn-Otis end-tidal sampler (Warren E. Collins, Inc., Braintree, Mass.), fitted with a paediatric face mask (Rendell Baker Soucek). Details of the sampling technique have been described elsewhere, and samples obtained by this method have been found to correlate closely $(r=0.91)^{3}$ with those obtained by the previously-validated modified Haldane-Priestley tube of Metz et al..$^{13}$

Samples were obtained immediately before lactose administration, and then at 30-minute intervals for 3 hours. Storage and analysis techniques have been described elsewhere. ${ }^{3}$ Results of hydrogen estimations were expressed as peak rise $\left(\left[\mathrm{H}_{2}\right]\right)$ above the basal level, in parts per million (ppm). Rises of more than $20 \mathrm{ppm}$ were regarded as positive, after the convention of Metz et al. ${ }^{14}$

\section{Results}

Three of 18 patients given lactose $0.5 \mathrm{~g} / \mathrm{kg}$ had positive breath hydrogen responses (Table 1). Of these, none developed symptoms. The breath tests in

Table 1 Lactose $(0.5 \mathrm{~g} / \mathrm{kg})$, positive responses

\begin{tabular}{lll}
\hline Case & $\begin{array}{l}\text { No of days from } \\
\text { onset of symptoms }\end{array}$ & $\begin{array}{l}\text { Rise in breath } \\
\left(\mathrm{H}_{2}\right) \text { in ppm }\end{array}$ \\
\hline 1 & 1 & 185 \\
2 & 4 & 26 \\
3 & 0 & 90 \\
Repeat tests on positive responses & \\
1 & 5 & 16 \\
3 & 2 & 8 \\
\hline
\end{tabular}

2 patients who were studied again later in their illness became negative. Fifteen patients had negative responses to the $0.5 \mathrm{~g} / \mathrm{kg}$ lactose load (Table 2). None of these developed symptoms.

Of the 20 patients given $2.0 \mathrm{~g} / \mathrm{kg}$ lactose, 8 had positive breath tests (Table 3), and one of the 2 studied later in the illness became negative, while the other remained positive. Again, none of these patients had symptoms of lactose intolerance. Of the 12 patients with negative breath tests after lactose $2.0 \mathrm{~g} / \mathrm{kg}$, one (Case 29) had an exacerbation of diarrhoea, and tests on his stools showed $0.5 \%$ reducing substances, a result that suggested probable

Table 2 Lactose $(0.5 \mathrm{~g} / \mathrm{kg})$, negative responses

\begin{tabular}{lcc}
\hline Case & $\begin{array}{l}\text { No of days from } \\
\text { onset of symptoms }\end{array}$ & $\begin{array}{l}\text { Rise in breath } \\
\left(\mathrm{H}_{2}\right) \text { in ppm }\end{array}$ \\
\hline 4 & 5 & 2 \\
5 & 12 & 2 \\
6 & 10 & 0 \\
7 & 5 & 1 \\
8 & 7 & 2 \\
9 & 6 & 1 \\
10 & 17 & 0 \\
11 & 28 & 12 \\
12 & 4 & 12 \\
13 & 8 & 6 \\
14 & 6 & 8 \\
15 & 5 & 3 \\
16 & 32 & 0 \\
17 & 4 & 3 \\
18 & 4 & 6 \\
19 & 0 & 5 \\
20 & 4 & -1 \\
\hline
\end{tabular}

Table 3 Lactose $(2 \mathrm{~g} / \mathrm{kg})$, positive responses

\begin{tabular}{lll}
\hline Case & $\begin{array}{l}\text { No of days from } \\
\text { onset of symptoms }\end{array}$ & $\begin{array}{l}\text { Rise in breath } \\
\left(H_{2}\right) \text { in ppm }\end{array}$ \\
\hline 21 & 18 & 21 \\
22 & 6 & 26 \\
23 & 10 & 101 \\
24 & 3 & 53 \\
25 & 5 & 27 \\
26 & 7 & 30 \\
27 & 5 & 55 \\
28 & 3 & \\
& 5 & 26 \\
24 & 5 & -8 \\
28 & 5 &
\end{tabular}

Table 4 Lactose $(2 \mathrm{~g} / \mathrm{kg})$, negative responses

\begin{tabular}{llc}
\hline Case & $\begin{array}{l}\text { No of days from } \\
\text { onset of symptoms }\end{array}$ & $\begin{array}{l}\text { Rise in breath } \\
\left(\mathrm{H}_{2}\right) \text { in ppm }\end{array}$ \\
\hline 29 & 11 & 1 \\
30 & 7 & 6 \\
31 & 7 & 17 \\
32 & 9 & 4 \\
33 & 6 & -3 \\
34 & 9 & 4 \\
35 & 5 & 1 \\
36 & 5 & -3 \\
37 & 8 & 1 \\
38 & 5 & -1 \\
\hline
\end{tabular}


lactose intolerance. If so, the breath test on that patient must be regarded as a false-negative result.

In neither dose group was there a change in mean stool frequency during the 24 hours after the load, compared with the 24 hours preceding it.

No significant differences in age, sex, race, duration of symptoms, nutritional status, or the presence of a stool pathogen were observed between those with a positive breath hydrogen response and those in whom it was negative.

\section{Discussion}

Clinical lactose intolerance occurred in only one patient of the 38 studied, in marked contrast to the prevalence of $77 \%$ found in a predominantly malnourished Mexican group by Lifshitz. ${ }^{5}$ Lactose intolerance was more common in those with more severe grades of malnutrition in the Mexican study.

Although rapid resolution of lactose malabsorption occurring soon after onset of the illness is evident in some of the patients who were restudied, in others it is detectable up to 18 days after the onset of symptoms. This is in keeping with the time-course observed in the clinical study of Lifshitz et al., ${ }^{5}$ who found about equal numbers of patients with 'early onset', 'late onset', and 'indeterminate onset' lactose intolerance. Nevertheless, our data suggest that closer study of the early days of the illness is warranted in seeking lactose malabsorption.

In distinction to the rarity in our study of lactose intolerance, which we define as a clinical phenomenon, there was a much greater prevalence of biochemical evidence of lactose malabsorption, as assessed by hydrogen breath testing. Positive breath tests occurred in 11 of 38 patients studied, and was more frequent at the higher lactose dose.

Lactulose ( $\beta$ 1, 4-galactosido-fructose) is a synthetic non-absorbable disaccharide observed to produce increased breath hydrogen excretion in a proportion of normal subjects. It possesses cathartic properties resulting from the production of breakdown products by the colonic flora. A recent study by Solomons et al..$^{15}$ has questioned the validity of assessing suger malabsorption in gastroenteritis by means of the hydrogen breath test. They administered $10 \mathrm{~g}$ lactulose to 5 Guatemalan children with gastroenteritis and found a lower concentration of hydrogen excreted in the breath than in the breaths of a control group of 10 normal children similarly treated. They attributed this to variations in colonic flora or to gut motility in gastroenteritis.

However, lactulose administration may not be an appropriate way of using the breath test in gastroenteritis.
In a separate study in adults, the production of breath hydrogen after lactulose administration has been shown to vary greatly in different normal individuals. ${ }^{16}$

In addition, anaerobic incubation of stool from normal individuals with a variety of sugars shows that hydrogen production from lactulose and from other sugar substrates do not necessarily mirror one another. This suggests that results obtained after lactulose administration cannot be extrapolated to other sugars. ${ }^{17}$

Alternatively, if gastroenteritis does reduce hydrogen production from all sugars, it may be that in using this test we have underestimated the prevalence of lactose malabsorption in our own series. We feel that this is unlikely considering the low prevalence of symptomatic intolerance.

In conclusion, the hydrogen breath test detects biochemical evidence of lactose malabsorption much more commonly than symptomatic lactose intolerance in gastroenteritis. The prevalence of clinically significant lactose intolerance during gastroenteritis in Birmingham was much lower than that reported from tropical countries.

We thank Sister Williams, Sister Twigg, and their staff for their help with this study, and Mrs Pamela Jackson for typing the manuscript.

The Children's Research Fund and the West Midlands Regional Health Authority provided financial support.

\section{References}

1 Kretchmer N. Child health in the developing world. Pediatrics 1969; 43: 4-11.

2 Feldman $R$ A, Kamath $K$ R, Sundar Rao $P$ S S, Webb J K G. Infection and disease in a group of South Indian families. I. Introduction, methods, definitions, and general observations in a continuing study. Am J Epidemiol 1969; 89: 364-74.

${ }^{3}$ Kamath $K \mathbf{R}$, Feldman $\mathbf{R} A$, Sundar Rao $\mathbf{P} \mathbf{S} \mathbf{S}$, Webb J K G. Infection and disease in a group of South Indian families. II. General morbidity patterns in families and family members. Am J Epidemiol 1969; 89: 375-83.

4 Gardiner A J. Gastroenteritis in Alice Springs. Med J Aust 1977; ii: Special supplement, 1-5.

5 Lifshitz F, Coello-Ramirez P, Gutierrez-Topete G, Cornado-Cornet $M$ C. Carbohydrate intolerance in infants with diarrhea. J Pediatr 1971; 79: 760-7.

- Barnes G L, Townley R R W. Duodenal mucosal damage in 31 infants with gastroenteritis. Arch Dis Child 1973; 48: 343-9.

7 Davidson G P, Barnes G L. Structural and functional abnormalities of the small intestine in infants and young children with rotavirus enteritis. Acta Paediatr Scand $1979 ; 68$ : $181-6$.

${ }^{8}$ Kerry K R, Anderson C M. A ward test for sugar in faeces. Lancet 1964; i: 981-2. 
9 McMichael H B, Webb J, Dawson A M. Lactase deficiency in adults: a cause of 'functional' diarrhoea. Lancet 1965; i: $717-20$.

10 Newcomer A D, McGill D B, Thomas P J, Hofmann A F. Prospective comparison of indirect methods for detecting lactase deficiency. $N$ Engl J Med 1975; 293: 1232-6.

11 Metz G, Blendis L M, Jenkins D J A. Letter: Hydrogen breath test for lactase deficiency. $N$ Engl J Med 1976; 294: 730 .

12 Tanner J M. Standards of normal growth. In: Foetus into man: physical growth from conception to maturity. London: Open Books, 1978: 167-205.

13 Metz G, Gassull M A, Leeds A R, Blendis L M, Jenkins D J A. A simple method of measuring breath hydrogen in carbohydrate malabsorption by endexpiratory samples. Clin Sci Mol Med 1976; 50: 237-40.

14 Metz G, Jenkins D J A, Newman A, Blendis L M. Breath hydrogen in hyposucrasia. Lancet 1976; i: 119-20.
${ }^{15}$ Solomons N W, Garcia R, Schneider R, Viteri F E, Argueta von Kaenel V. Hydrogen breath tests during diarrhoea. Acta Paediatr Scand 1979; 68: 171-2.

16 Gilat T, Ben Hur H, Gelman-Malachi E, Terdiman R, Peled Y. Alterations of the colonic flora and their effect on the hydrogen breath test. Gut 1978; 19: 602-5.

17 Gardiner A J, Tarlow M J, Symonds J, Hutchison J G P, Sutherland I T. Failure of the hydrogen breath test to detect primary sugar malabsorption. Arch Dis Child 1981; 56: 368-72.

Correspondence to Dr M J Tarlow, Department of Paediatrics and Child Health, East Birmingham Hospital, Bordesley Green East, Birmingham B9 5ST.

Received 14 February 1980 